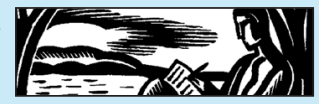

\title{
Celebrity, Scriptedness and Alleged Sexual Violence in Ghost-Written Autobiographies by Julian Assange and Samantha Geimer
}

\author{
Edward Saunders
}

Ludwig Boltzmann Institute for the History and Theory of Biography, Vienna

\section{ABSTRACT}

This article explores issues relating to the way scripts of sexual violence are employed or rejected in auto/biographical writing. It addresses ghost-written autobiographical responses to two famously unresolved cases of alleged malefemale rape: those of Julian Assange and Roman Polanski. In both cases, the alleged perpetrator was a famous man and the allegation of rape has not conclusively been proven in court. The article looks at rape as a narratological problem beyond the definition or symbolic meaning of the crime, and contrasts the narration from the perspective of an alleged perpetrator (Assange) with that of a victim (Samantha Geimer), addressing the way the act of sexual violence becomes a point of orientation in the lives of both - perhaps disproportionately so. In both cases, the management of the autobiographical account through the use of ghost-writers focuses attention on the constructed nature of the life narrative. In cases relating to famous men, reflecting the impact of media reporting is a necessary counterpart to the consideration of the auto/biographical text.

\section{WHO GETS DISHONORED?}

In 1994 or 1995, the filmmaker and screenwriter Jill Craigie (1911-1999) told guests at a London dinner party that she had been raped many years before. Her audience was a distinguished group, including Salman Rushdie and Jon Snow. ${ }^{1}$ The incident was alleged to have happened in 
1952 and the man accused was the writer and journalist Arthur Koestler (1905-1983), a friend of her husband, Michael Foot. It was a case of acquaintance rape, the form of sexual violence most likely to go unreported, and it occurred at a time when Koestler was a well-known figure, perhaps one reason Craigie did not report the incident. However, there could be no recourse to justice in the case because the accusation was made long after Koestler's death. Biographers and historians writing about Craigie or Koestler have, therefore, been required to discuss the evidence in the absence of a legal process: a difficult and often fraught undertaking. ${ }^{2}$ David Cesarani was the first to make the allegation public in his 1998 biography Arthur Koestler: The Homeless Mind. Significantly, the allegation damaged not only Koestler's reputation, but also the biographer's: as Matthew Price writes, 'The ethics of the scribe as well as those of his subject were suddenly in question.' ${ }^{3}$ The furore that accompanied the publication of Cesarani's book is emblematic of the difficulties the life-writer confronts when narrating a topic as sensitive and political as sexual violence.

One of the reasons that Cesarani was criticized is that rape claims made against famous men - those whose distinguished lives make them 'worthy' of being written about - are sometimes decisive in determining public perceptions and the biographical reception of those men. Regardless of whether the accused is found innocent or guilty, the reputational damage can be lasting. However, the reality is still that sexual violence is an underreported crime, difficult to report, let alone successfully prosecute, for a variety of reasons both structural and situational, and one for which the female victim is frequently blamed. ${ }^{4}$ By foregrounding the prevalence of narratives or 'scripts' of sexual violence, this article aims to show how reader reception is shaped in public discourses, setting the complex interplay of sexual violence, celebrity and reputation management against the background of a broader theoretical discussion about the ways rape is narrated or interpreted.

If there has been a cultural shift in the way rape is reported and narrated, it has only been a partial one. A brief illustration of the perceived cultural shift (at least in Western societies) can be found in J. M. Coetzee's novel Diary of a Bad Year (2007). A fictional rape survivor relates what a Mexican policeman told her. He warned her not to report the crime, saying: 'you know, dishonour, infamia, is like bubble gum, wherever it touches it sticks.' His implication is that the woman's reputation would be damaged. Her response is robust and defiant, 'You know what I said? I said, This is the twentieth century, capitano (it was still the twentieth century then). In the twentieth century, when a man rapes a woman it is 
the man's dishonour. ${ }^{5}$ The woman then reports the rape and the perpetrators are arrested. This fictional anecdote illustrates how the status of sexual violence in Western societies is supposed to have changed, even if it has not. Previously women were blamed for sexual attacks against them, and men were absolved for their sexual weakness. While victim blaming is an issue that will be returned to later, nowadays, or so this narrative goes, the reputational damage tends to be done to the man and not to the woman. However, the fact that not everything has changed in public debates can be evidenced by paying closer attention to the narratives implemented in allegations of sexual violence against famous men and how these are resisted.

Building on the notion of 'scriptedness,' the aim of this article is to explore the implications of existing debates on rape and representation within the genre of auto/biographical writing, taking two ghost-written autobiographies as case studies, but also referring to other high-profile cases. These two texts are The Unauthorised Autobiography (2011) by Julian Assange, written in collaboration with Andrew O'Hagan, and The Girl: A Life in the Shadow of Roman Polanski (2013) by Samantha Geimer, written in collaboration with Judith Newman, and with the assistance of Geimer's lawyer, Lawrence Silver. One is a text based on transcribed interviews with a man who would seek to defend himself from a rape claim. The other is the story of a woman famous only as a rape victim. These two very different cases are highly specific examples which help demonstrate broader aspects of discourses on rape within life-writing as a whole. These ghostwritten texts are neither conventional single-author autobiographies nor third-person biographies, but hybrid auto/biographical forms. ${ }^{6}$

While there can be no single typology of how unproven rape allegations are dealt with in auto/biographical writing, the difficulties and pitfalls are apparent even before one looks at case studies. These difficulties are shared, for all auto/biographical writers have to negotiate the same discourses relating to the representation of sexual violence. The central issues in these debates are familiar: the problematic attribution of 'victimhood,' the concepts of honor and dishonor, the definition of consent, the importance of race and class, and perceived cultural bias in favour of the man. Familiar too is the martyr-perpetrator binary that is often at work, the way that perpetrators attempt to present themselves as victims, or the invocation of worthy causes (politics, art) to excuse, or at least distract from, aggressive sexual acts. As will be discussed, it is the familiarity of these elements in the narration of sexual violence that reveals the presence of discourses that can be termed, following Sharon Marcus's use of the term, 'scripts' of sexual violence. 


\section{AMBIVALENT SPECTATORS}

The issue of how rape is represented has been explored in diverse medial contexts, particularly in literary fiction and film, in books such as Rape and Representation (1991a), edited by Lynn A. Higgins and Brenda R. Silver, or Tanya Horeck's monograph Public Rape: Representing Violation in Fiction and Film (2004). The narratives employed in media reporting have been discussed by M. Cristina Alcalde (2009), who examines processes of victim blaming and 'revictimization' of women in the Peruvian media. ${ }^{7}$ In the context of autobiography, sexual violence is discussed in the work of Linda Martín Alcoff and Laura Gray-Rosendale (1996) as well as in Leigh Gilmore's study The Limits of Autobiography: Trauma and Testimony (2001). Of course, life-writing genres differ from most feature films and literary fiction in their relationship to the veracity of what they describe: life-writing typically claims to tell historical truth. On the other hand, both biographies and autobiographies have demonstratively subjective authorial voices.

The way rape is represented in non-fiction media, therefore, is often highly problematic. The example used by Horeck of the documentary film Raw Deal: A Question of Consent (2001) shows how even authentic film footage of a supposed rape is open to divergent interpretations and is embedded in the complex discourses of sexual violence. The film discusses a real disputed rape case that occurred at an American university in 1999 and demonstrates the difficulties of interpretation through interviews with some of those involved in the case, including the ostensible victim. The film's subject is the inherent ambiguity of whether a rape took place or not, but Horeck suggests that this ambiguity derives at least in part from the viewer's feeling of discomfort at the potentially pornographic content. She writes, 'it is easier to believe that such things don't take place, it is better to believe that you did not just see a rape in the raw. ${ }^{8}$ Horeck's conclusion about the importance of spectatorship indicates what is common to all forms of mediation of sexual violence. In her words, 'the ambivalence of spectatorship, and the question of our complicity and participation in scenes of violence. ${ }^{9}$

The problem of spectatorship is crucial and relates to the issue of 'double violation' to be discussed later. As a medium, however, life-writing contains a range of associated 'ambivalent' issues. The challenge for writers of biography derives from the history of the genre, which has traditionally focused on the lives of successful men, constructing narratives to help readers empathize with these figures. Allegations of sexual violence threaten not only to prevent the formation of any feeling of empathy for the biographical subject, but also question the worthiness of the biographical subject as such. Meanwhile, for writers of autobiography 
involved in rape cases, as well as for writers of biographies about rape victims, such as Carl Rollyson's To Be a Woman: The Life of Jill Craigie (2005), which discusses the Koestler case mentioned above, the problem is similar but slightly different: they need to find ways to convince readers of their side of the story without damaging the crucial illusion that they are delivering honest or impartial insight into inner lives. Perhaps even more difficult is the position of the ghost-writer, whether acting for perpetrator or victim, who has to support the autobiographical subject in their narration while simultaneously creating an illusion of immediacy and authenticity in a carefully stage-managed text. Not only spectatorship should be considered, therefore, but also artistry: how the act of sexual violence is reconstructed by authors in ostensibly 'truthful' life-writing genres.

\section{A CONTEMPORARY DEBATE}

The shift in attitudes towards sexual violence has yet to reach a critical mass both in Western contexts and globally. However, despite the immense historical effort required to shift the responsibility for rape and sexual violence from women to men, some diagnose a crisis in contemporary feminist approaches to the issue. Alcoff writes, 'We are in a period of confusion about the actual nature and scope and reference points of sexual violence. From debates over the accusations against Assange to debates over the trail of accusations against Dominique Strauss-Kahn, the wider publics - even feminist publics - are not sure what to think. ${ }^{10}$ In part this is because high-profile allegations of rape have wide-reaching consequences for the lives and careers of the accused and are perceived by some to be instrumentalized for political purposes, as in the StraussKahn and Assange cases. Another reason may be the perennial accusations against sports stars in tabloid newspapers - some genuine, some not. Suspicion of 'kiss and tell' stories may lead to distorted public perceptions of rape as a crime, due to the occasional abuse of victim status by those lacking scruples. Alcoff's own solution to current confusions is to focus on forms of resistance and to see language as the primary battleground, for language provides victims of sexual violence with the means to express their experience, while at the same time helping erase or trivialize it. ${ }^{11}$ Drawing on the work of Michel Foucault, she suggests thinking about the following questions in the narration of sexual violence: 'Who is speaking? Who has authority? Who is reduced to the role of the listener? [...] Whose claims get discredited before they are out of the gate?'12

These questions are essential to analyzing life-writing about sexual violence. The examples of Assange and Strauss-Kahn given by Alcoff are 
indicative of people who have achieved much in public life, but whose life stories were instantly affected by rape accusations. Both have disputed that what they had done was rape and both have tried to limit damage to their reputations. Thinking about the examples of Assange, Strauss-Kahn and similar cases, like the Roman Polanski affair, or indeed the childabuse accusations made against Woody Allen, can provide some clues as to what the fall of the 'hero' means for the construction of a life narrative. In examining allegations of sexual violence made against important or famous people, this issue is never far away - biographical subjects are usually people known for some public involvement, act or publication, who are discredited by actions in their personal life, and whose professional achievements are then questioned. Current confusions about how to interpret rape accusations may well stem from the same life-work problem, which is the familiar terrain of the 'biographical fallacy': there is an unwillingness to see work reduced to a life story, but a concurrent difficult in separating individual achievements from that story. And while there is no room for the discussion here, it is worth considering whether representatives of politics and the arts are proportionately more affected by the reputational damage from rape allegations than, say, a natural scientist might be.

\section{SCRIPTS OF DENIAL}

The risk in such confusions is that attempting to mitigate sexual violence means reinforcing ingrained attitudes to sexual violence. One of the most influential ideas from the critical literature on rape is Sharon Marcus's notion of rape as a 'script.' Her concern is to understand the narratives that enable sexual violence, such as 'women are rapable, women deserve rape / women provoke rape, women want rape, women are ashamed of being raped / women publicly lie about being raped. ${ }^{13}$ It is also possible to identify cultural scripts of rape denial, as shown in the study of convicted rapists by Diana Scully and Joseph Marolla conducted in 19801981. Scully and Marolla divided the interview material they gathered into groups of 'deniers' and 'admitters' and looked for similarities between individual accounts. They observed that those who admitted rape tried to justify their actions by blaming "forces beyond their control [...] which reduced their capacity to act rationally. ${ }^{14}$ Deniers, meanwhile, employed two main lines of argument. The first form of denial identified by Scully and Marolla is 'the cultural view of men as sexually masterful and women as coy but seductive. Injury was denied by portraying the victim as willing, even enthusiastic, or as politely resistant at first but eventually yielding 
to "relax and enjoy it". ${ }^{15}$ The second is the portrayal of the victim as "the type of woman who "got what she deserved". ${ }^{16}$ As if to corroborate Sharon Marcus's later notion of the rape script, the authors note that it 'is important to remember that deniers did not invent these justifications. Rather, they reflect a belief system which has historically victimized women by promulgating the myth that women both enjoy and are responsible for their own rape. ${ }^{17}$

Another account of the scriptedness of rape denials and justifications is made by Joanna Bourke in her study, Rape: A History from 1860 to the Present Day (2007). Bourke outlines a series of myths that have been used by men to excuse their actions, including the idea that rape is not physically possible, which sometimes invokes the "metaphor of a vagina as a scabbard', capable of rejecting the penis; the idea that women frequently lie, or the 'pervasiveness of false allegations'; and the attempt to relativize the act, to distinguish psychologically or physically coercive 'bad sex' from the crime of rape. Beyond these ideas, Bourke claims that ' $[\mathrm{t}]$ he most potent item in the rapists' charter is that "no" often does not mean "no".'18 These two sets of analyses illustrate how scripted the process of denial can be. These scripts deem women as incapable of expressing what they want without lying, see women as enjoying sex if they are physically capable of having it, and suppose a gradient of sexual violence with serious and less serious forms that are always open to interpretation regardless of any explicit denial of consent.

\section{SMOKESCREENS: ASSANGE'S UNWANTED AUTOBIOGRAPHY}

Together with the Dominique Strauss-Kahn case, the double rape claim made against Julian Assange has been one of the most widely discussed cases in recent years. These two cases have become paradigmatic in public discussions of sexual violence, and the Strauss-Kahn case in particular has been discussed by feminist critics (Davis 2012; Rouyer 2013). While the 'DSK' case has also been highly mediated, not least via the disputed feature film Welcome to New York directed by Abel Ferrara (France / United States 2014), the Assange affair is particularly interesting because of the explicit linking of the rape allegation to a supposed international governmental conspiracy to arrest the figurehead of WikiLeaks. While on bail at Ellingham Hall in Norfolk, Assange decided he wanted to write a memoir in order to tell his story. Given that he was campaigning against his extradition to Sweden to face rape charges, he had both financial and reputational reasons for doing so. The resulting text, Julian Assange: The Unauthorised Autobiography, was disowned by Assange and published 
against his wishes in fulfilment of a $£ 600,000$ contract by the Edinburgh publisher Canongate in 2011. The title plays with the publishing term of the 'authorized biography', which is, as Carl Rollyson describes, a text 'written with the full cooperation of the subject or of the subject's literary estate, his family, and friends.' ${ }^{19}$ An unauthorized biography, by contrast, is normally 'written in a completely independent fashion. ${ }^{20}$ Assange's 'unauthorized' autobiography occupies a middle position, as it was written with the agreement of the author, but published without it. The ghostwriter, the novelist Andrew O'Hagan, has given his account of the book's creation in an extensive essay in the London Review of Books in March 2014. O'Hagan had requested from the publishers that he remain anonymous, being more interested in exploring 'how porous the parameters between invention and personality are,' but his name was later revealed in a statement by Assange. ${ }^{21}$ Assange objected to the text's publication, but he worked with O'Hagan for more than five months in 2011 and never repaid the advance for the text to Canongate. ${ }^{22}$ The resultant book is based on O'Hagan's extensive interviews with Assange and it can only be assumed that this ghost-written book contains sufficient veracity that it is representative of Assange's statements. It is, of course, a construction and O'Hagan likened the process to "writing a voiceover for a real person who isn't quite real' - although the same could be said of any autobiography, regardless of the author. ${ }^{23}$

Even if it was not his primary objective in commissioning and helping write the text, Assange used the 'autobiography' to maintain his innocence in the rape case, particularly in the chapter titled 'Blood'. His denial rests in part on a statement of good character and in part on an attempt to discredit the system which allowed the allegations to be made. Assange says, 'I may be a chauvinist pig of some sort but I am no rapist, and only a distorted version of sexual politics could attempt to turn me into one. ${ }^{24}$ Straightaway, therefore, Assange is adopting a narrative strategy that underpins the notion of rape 'scripts': the notion of the public lie that maligns the innocent sexual partner. This does not mean that Assange is lying, only that what he says corresponds to particular recurrent ways of denying and excusing sexual violence. It also echoes the words of one biographer of Dominique Strauss-Kahn, who was reported in the American press as having said 'This man is a seducer, he's a typical French lover, but he's not able to rape a woman. ${ }^{25}$ Incorrigible seducers or chauvinist pigs, but not rapists: both of these pronouncements use an admission of the subject's flawed but not debased character to attempt to defend Assange and Strauss-Kahn from more grave charges. In Assange's Unauthorised Autobiography, this protestation of innocence is bolstered by the implicit claim of the first-person text to authenticity, 
but simultaneously complicated by the book's unauthorized (or rather 'authored') status.

Were this the only attempt on the narrative level to sideline the rape accusation in Assange's book, it might not seem remarkable. However, Assange goes much further. The campaign against sexual violence which according to UN data affects at least a third of women globally, if not more ${ }^{26}$ - is directly linked by Assange with the supposed neoconservative conspiracy he is fighting against. At the same time, this also corresponds to a familiar feature of rape scripts, namely that the alleged victim is a feminist, where this word is also associated with delusion and hatred of men. A particularly vivid version of this can be found in The Unauthorised Autobiography, which seeks to discredit the claims made against Assange by two women who, according to him, are connected with the Swedish feminist movement. Assange says the following: 'you'd have to say, with the best will in the world, that Sweden is one of the few countries in the world where hardcore feminism has entered the mainstream. Indeed, the decision to go to Afghanistan was mainly based on feminist principles: despite the women's movement's traditionally anti-war stance, they deplored, understandably, the Taliban's treatment of women and sanctioned, less understandably, bombing as a way of opposing it.' ${ }^{27}$

It is reasonable to question what connection the NATO-sanctioned war in Afghanistan since 2001 has with the accusation of rape. It might be dismissed as a simple diversion tactic. However, whether consciously or not, it resembles the critique of what is termed 'carceral feminism,' a discourse which maintains that the imperialist state has jumped on an anti-patriarchal bandwagon. This is an unsettling left-wing political position that also posits the notion of 'homonationalism' (the alignment of gay rights with military interests) and decries 'women-saving' justifications for military violence or incarceration policies (Spade and Willse 2014). Furthermore, the rape claims made against Assange have been interpreted in this light in the work of Dean Spade and Craig Willse, who describe them as 'a method of control and neutralization of people deemed threatening to the U.S. government and its clients. ${ }^{28}$

It is important to note that this critique does not just occur outside of the autobiographical narrative, but is also present on the textual level. Assange's use of the word 'hardcore' implies that Swedish feminism is extremist, rather than egalitarian. He also uses phatic speech ('you'd have to say, with the best will in the world') as a form of disclaimer for what he is about to say, before proceeding to distract through reference to global politics from the actual relevant matter: whether the sexual acts between Assange and the women concerned were fully consensual or not (he claims they were). 
The parallels and differences between the Assange and StraussKahn cases cannot be ignored. Left-wing sympathies for Assange have tended to absolve him of the same crime of which they indict StraussKahn despite the fact that, at least legally speaking, the opposite is true: at the time of writing, the case against Strauss-Kahn in New York has been settled without conviction, while Assange continues to resist arrest in London. The role of any future biographer of both men will be to sift through the details of two complicated situations, but one of the anomalies they may notice is that of the differences in reception. In a joint article in The Guardian, two anti-rape campaigners, Katrin Axelsson and Lisa Longstaff, wrote in support of Assange: 'the allegations against him are a smokescreen behind which a number of governments are trying to clamp down on WikiLeaks for having audaciously revealed to the public their secret planning of wars and occupations with their attendant rape, murder and destruction. ${ }^{29}$ Only a year before, Katrin Axelsson had written critically of Dominique Strauss-Kahn, 'If the prosecution against DSK is dropped, the age-old myth that women, not men, lie about rape will prevail once more. ${ }^{30}$

Commenting on the problems the Dominique Strauss-Kahn case seemed to cause for feminist critics, Kathy Davis asks, 'how do feminists become entrapped in the ubiquitous rape narrative - a narrative which requires a perfect victim with a spotless past and a clear-cut case of nonconsensual sex with the use of violence?' ${ }^{31}$ Similarly, Muriel Rouyer has written that the Strauss-Kahn accusations 'unleashed a malestream discourse which minimized his alleged crime, victimized him rather than the alleged victim, and defended his right to privacy [...] while concealing power inequalities and broader sexual violence. Representations of DSK by his supporters tapped into three narrative frames: seduction, conspiracy and indignation. ${ }^{32}$ Rouyer goes on to argue that there was no conspiracy, rather that it was 'DSK's communications advisors [who] were the ones manipulating public opinion. ${ }^{33}$

What is true of the Strauss-Kahn affair in this respect is also true of the rape allegations made against Assange and the discussion of them in The Unauthorised Autobiography. It is worth remembering Alcoff's questions: in The Unauthorised Autobiography, who has authority? And whose claims are being discredited? Clearly, the authority lies with Assange and it is his accusers' claims that are being discredited (along with those of the Swedish state). Like Strauss-Kahn's advisors, Assange too seems capable of manipulating public opinion, for in the Assange case the accusers have also been publicly discredited. For example, the first of his accusers, 'Ms A-', is described as 'a little neurotic' although 'everything seemed fine' the night after they had 'had sex several times.' ${ }^{34}$ She is also made out to be 
boastful when they are both at a party the following day: 'It became obvious she had told people we had been sleeping together. ${ }^{35}$ Even without reading between the lines of Assange's brief description, therefore, it is evident that 'neurotic' woman A- is not only eager for sex, but is also looking for publicity.

'Ms W-', with whom Assange was also sleeping at the same time, is honored only with the note that she was 'a little vague' towards Assange, and their relationship is described as 'fun' but 'going nowhere. ${ }^{36}$ Both women are implied to be emotionally needy and the suggestion is made that they may have been acting on someone's orders: 'I wasn't paying enough attention to them, or ringing them back,' says Assange, 'I wasn't a reliable boyfriend, or even a very courteous sleeping partner, and this began to figure. Unless, of course, the agenda had been rigged from the start. ${ }^{37}$ Here too, then, the narrative strategy is to discredit the accuser in whatever way possible: here by suggesting emotional neediness and extending this into a suggestion of political corruption.

Following the double rape allegation, Assange professes his incomprehension at how it had come about, and claims he saw only a very few possibilities: "malice after the fact, a joint plan to entrap me, or a terrible misunderstanding that was stoked up between them. ${ }^{38}$ After several pages detailing perceived irregularities and inconsistencies relating to the accusations, Assange concludes, 'The rape allegation was made, withdrawn and then made again, in the course of which I was already criminalised for the horrendous feat of having had consensual sex with two women in Stockholm in August 2010. ${ }^{39}$ Against these statements of denial needs to be placed - by way of necessary contextualization - what Andrew O'Hagan (as the real author of these passages) has said about Assange's account of the rape allegations: 'in all my time with him he hadn't really clarified what happened. ${ }^{40}$

The point here is not to attempt to psychoanalyze Assange's ghost-written text in order to adjudicate on his innocence or guilt. Rather, it is to look at the text as an account of alleged (and unproven) sexual violence in a life-writing context. It is Assange who is the victim of the allegations, it is implied, and the women - neurotic, vague, needy, and possibly in the pay of the CIA - are simply lying (and what is more, they may just have got worked up over nothing). Then, three years after the publication of the book, its real author or co-author, Andrew O'Hagan, writes in an article that he was never given a clear idea of the actual events, thereby also casting doubt on the denials made in Assange's name and highlighting the way the question of consent is hurriedly passed over in the text. O'Hagan distances himself from the book's account of the allegations, describing Assange's linking of the rape accusations with his campaign 
against secrecy as an 'old conflation,' and suggests that Assange loses 'moral authority' over the issue: 'I tried to spell this out to him while writing the book, but he wouldn't listen, sometimes suggesting I was naïve not to consider the rape allegations to have been a "honey trap" set by dark foreign forces, or that the Swedes were merely keen to extradite him to America. ${ }^{41}$ O'Hagan also notes that, although requested to, Assange neglected to review 'the Swedish chapter' before publication. ${ }^{42}$

Whether one supports Assange or not, it is problematic that a text that has self-defence as an implicit goal resorts to narrative strategies that so closely resemble patriarchal scripts of sexual violence. That Assange also demonizes feminism in his denial of sexual violence only lends weight to Carine Mardorossian's claim that rape is 'constantly subjected' to a 'metaleptic reversal [...] that retrospectively constitutes effects as origins and causes. ${ }^{43}$ As Mardorossian notes, reading political motivation into anti-rape activism is a strategy that seeks to divide "real victims [...] from the "angry feminists" whose anger, as a result, is seen as self-contained and pathological. ${ }^{44}$ Similarly, in the introduction to their volume Rape and Representation (1991b), Lynn Higgins and Brenda Silver pose the following important questions: 'what happens to women who go public about their violation? If they escape the dominant fate of silencing and erasure, what price do they pay? Will their speech, their protest, be reinscribed in the patriarchal economy as figures of a female violence even worse than that perpetrated against them? ${ }^{45}$ It is doubly problematic, therefore, that in Assange's Unauthorised Autobiography the women are given cursory and negative character assessments at the same time as their motivations are questioned. By also attempting to discredit the system that works to protect potential victims of sexual violence, the text (regardless of its ostensible author's true actions) inevitably colludes with scripts of rape denial which seek to blame women for rapes committed against them. It reveals the resilience of victim blaming discourses and, despite of its troubled authorship, demonstrates how the life narrative is enlisted as a strategic mechanism to influence perception of the autobiographical subject in the public sphere.

\section{VIOLATION AND MEDIATION: SAMANTHA GEIMER'S RESPONSE TO THE POLANSKI CASE}

Due to its unresolved nature and the fame of the man accused, the Californian court case against Roman Polanski for unlawful sex with an underage girl in 1977 has become a perennial media story. Although convicted of the crime (but not the more serious allegation of rape) and fearing re-sentencing at the point he thought he would be freed, Polanski famously fled the United States for Europe. When the story made 
headlines again in 2009, Samantha Geimer, née Gailey, the woman whom Polanski had sexually assaulted, decided she wanted to relinquish her poorly guarded anonymity and finally have her say on the story that had defined her life, as much as Polanski's. As noted above, The Girl: A Life in the Shadow of Roman Polanski (2013) was written by Geimer together with her lawyer Lawrence Silver, with the assistance of an additional ghostwriter, the journalist Judith Newman. Although the book is written in the first-person, and only Geimer's name appears on the book's cover, both Silver's and Newman's names are displayed on the title page and clearly accredited in the acknowledgements. Here the effect of the book's ghostwritten status is quite different: the problem of authorship is minimized by clearly accrediting the authors, and in using her lawyer as a co-author in a first-person narrative, Geimer's book benefits from increased authority as a legally-advised piece of writing.

Geimer's book is about taking possession of a story deeply personal to her but which she has long been excluded from. It is a story discussed in a number of non-fiction life-writing genres, including numerous biographies of Polanski, Polanski's own autobiography Roman by Polanski (1984), as well as at least two documentary films, Roman Polanski: Wanted and Desired (2008) directed by Marina Zenovich, as well as Roman Polanski: A Film Memoir (2011) directed by Laurent Bouzereau. Even the book's dustjacket marks this ownership of the story, displaying one of the photographs of the 13-year-old Samantha taken by Polanski on the day he assaulted her, to which, as the book states, she has the rights. As a response to sexual violence, the book takes a particularly interesting stance. On the one hand, Geimer is clear that she considers herself to be a rape survivor and is keen to correct some of the 'lies' that have been spread over the years, including in Polanski's own autobiography. ${ }^{46}$ On the other hand, Geimer shows that she is not embittered towards Polanski and believes that the ongoing legal proceedings against him were caused by a corrupt judge. ${ }^{47}$ This view is confirmed and supported by her co-writer Silver in his afterword.

Although Geimer's sympathy for Polanski is a remarkable aspect of her autobiography, she is also critical of the way she was depicted in Polanski's autobiography Roman (1984). In that book, in words comparable in sentiment to those used by Assange ('I was [...] criminalised for the horrendous feat of having had consensual sex'), Polanski writes 'In all my premonitions of disaster, one thought had never crossed my mind: that I would be sent to prison, my life and career ruined, for making love. ${ }^{48}$ Geimer reflects on these words and how they correspond to her experience, as well as to the question of whether what Polanski did could be considered rape: 'I knew I hadn't wanted to have sex with Roman, but did that make it rape? I thought rape had to be violent. ${ }^{99}$ While Geimer does talk about her experience as rape, she particularly objects to Polanski's 
use of the phrase 'making love,' asking 'On what planet could what happened ever be considered "making love"?'50

However, Geimer immediately qualifies this statement by saying 'Still, I was not brutalized. I was not dragged into the woods. I never felt in physical danger. ${ }^{51}$ In doing so, Geimer is highlighting one of the main problems associated with so-called 'acquaintance rape,' into which category both the Polanski case and the allegations against Assange fall. Mary White Stewart describes acquaintance rape as an unreportable crime. According to White Stewart, 'Women who have been raped by men they know consider not only how others will see their behavior in the situation but also the long-term impact of their reaction in the specific situation on others in their social world. ${ }^{52}$ In interviews White Stewart conducted, those who did not report acquaintance rape justified their decision as follows: 'they would not be believed; it would ruin their lives; it just was not worth it. ${ }^{53}$ It is also useful to recall Alcoff's description of the 'poverty' of the contractual understanding of consent, which she argues is not adequate for 'relations involving familial bonds, or any bonds of affect and friendship. ${ }^{54}$

The difficulty for survivors to understand their experiences as rape is further complicated by a particular aspect of scripts of sexual violence: the narrative of cultural difference. The claim that a particular man accused of sexual violence is merely culturally misunderstood recurs with surprising frequency. As noted above, Dominique Strauss-Kahn is described as a 'typical French lover' by his biographer, while, as David Cesarani has noted, Arthur Koestler's reputation for unwanted advances was explained away by enlisting the author's Hungarian origins as an excuse. ${ }^{55}$ With reference to Polanski, Geimer writes, 'I heard that older men seducing young girls was quite the thing where he came from. ${ }^{56}$ Later, describing an outlandish statement by a psychiatrist in Polanski's probation report which used cultural difference as a mitigating factor, Geimer states pithily, 'Don't blame the man; blame the (foreign) culture. ${ }^{57}$ That cultural difference is a major complicating factor in not only the narration but also the definition of sexual violence is underscored by Alcoff when she writes, 'Stereotypes of cultural difference continue to attribute rationality, emotionality, sexual intensity, and the fervor of cultural and religious commitments differentially across the globe, and nowhere are the effects of this more obvious than in regard to rape. ${ }^{58}$ To combat this and other ways of excusing rape, Alcoff proposes replacing the term 'consent' with that of 'willingness,' because this word 'invokes an image of a whole person whose will has been engaged in the event or process. ${ }^{59}$

As previously noted, a major aspect of Sharon Marcus's notion of the rape script is the way women are treated as inviting or deserving rape and are denigrated for their previous sexual experience. In his account of the 
incident in his autobiography, Polanski does not shy away from the topic of sexual experience, writing 'There was no doubt about Sandra's [i.e. Samantha's] experience and lack of inhibition. ${ }^{60}$ Geimer, meanwhile, notes that she exaggerated her sexual experience to Polanski so as not to appear prudish, and she claims that she was lucky that the Robbins Rape Evidence Law came into effect in 1975, a so-called 'rape-shield law' that prevented her sexual history being used in court. ${ }^{61}$

Victim blaming is a phenomenon that has affected Geimer personally. When her identity became semi-public knowledge in the neighborhood, her best friend's father refused to let them see each other any more: 'He and my mother argued loudly. He said something about me being a slut and that Terri couldn't come to the house any more.' Geimer also links this event with a common kind of victim blaming, describing the mentality as 'you must be as guilty to have been a rape victim as the rapist was to rape you. ${ }^{62}$ She provides a withering critique of the way she has been blamed and Polanski absolved in a commentary she makes on an apologist newspaper piece that appeared in the aftermath of Polanski's arrest in 2009: 'But this is the quality of insight that passes for journalism. He couldn't have raped that girl, because the thirteen-year-old was a skank, had been pimped out by her ambitious mom, and besides, all people who do bad things are stupid, ugly, and look like criminals. ${ }^{63}$

Geimer has suffered what may be termed the 'double violation' caused by highly mediated rape cases. In a widely-received article published in the Los Angeles Times in 2003, Geimer talked not only about her perception of the injustices done to Polanski by the American legal system, but also about the way she and her family suffered at the hands of the press: 'People don't understand that the judge went back on his word. They don't know how unfairly we were treated by the press. Talk about feeling violated! The media made that year a living hell and I've been trying to put it behind me ever since. ${ }^{64}$ The phenomenon of 'double violation,' where the mediation of sexual violence or the instrumentalization of sexual violence in a polemical way exacerbates the trauma it caused, has been described by Ananya Jahanara Kabir as "the "collateral damage" to the privacy of women caused by rhetorical necessity. ${ }^{\prime}{ }^{5}$

As Geimer's book illustrates, this is very much the phenomenon that she has been subject to, a fact also acknowledged by Polanski in the autobiographical film, Roman Polanski: A Film Memoir (2011). Her regrets begin with the amount of information about her encounter with Polanski that she revealed, implying that she would have lied to protect her reputation had she not still been high on methaqualone: 'I never would have been so honest if I hadn't been so high. ${ }^{66}$ She also describes her frustration with a media industry that ignores her voice and the fact the she would like to 
draw a line underneath the story, writing of her 'loathing of gadflies' who make a living from her life story. ${ }^{67}$ Geimer is angry about the way justice is done, about the publicity and the exploitation of the celebrity status of the trial, especially when it returns to haunt her in 2009: 'My case would be tried not only in the court, but also in the media. All the stories about me would be salivated over again. My crime? Being the rape victim of a Hollywood celebrity. ${ }^{\prime 68}$

While Kabir's account of double violation draws attention to the academic's own task in discussing rape ('fragile to the point, perhaps, of irrelevance') ${ }^{69}$ Geimer's narrative highlights why celebrity status led to the victimization of Polanski as perpetrator. Her suggestion is that he was 'lied to and manipulated by [a] corrupt criminal justice system,' for the reason that his 'fame and power made everyone involved in the case worry about themselves in relation to it. ${ }^{70}$ Several academic accounts have noted the media's role in shaping the guilt or innocence of the defendant in sexual violence cases (e.g., Smith 1998; Sasse 2007), but Geimer's narrative is unique in that she links her perception of the injustice done to Polanski to her critique of his own autobiographical narrative, as well as to the phenomenon of double violation. What is more, Geimer understands that the crux of the matter is the crisis celebrity rape cases cause in public discourse, an issue that mirrors the very problem of narrating sexual violence that she repeatedly comes back to.

It has long been argued that life-writing attempts to foster empathy in the reader with regard to the subject (e.g., Frank 1985). The assumption is that readers and writers of auto/biography are looking for parallels between their own life and the life being portrayed: the inevitable process of comparison is related to a desire for identification. The perceived need to protect the famous subject from detractors, or indeed their need to protect themselves, feeds media speculation and contributes to the outpouring of polarized commentary that can accompany such cases. Geimer combines this insight effectively with a polemic against the scripts of denial that seek to shift blame towards the victim and the media which exploit the rape survivor's trauma. Geimer does not only wish Polanski's ordeal would end, she shows how she, too, is a person to be empathized with and how rape scripts conspire to blame the victim.

\section{CONCLUSION}

While attitudes towards sexual violence have no doubt changed significantly since the Polanski case, it is still not the case (and nor is it ever likely to be) that reporting rape is something that can be done straightforwardly 
or without risking reputational damage. It remains a crime that is underreported and one in which victims are stigmatized as well as perpetrators. In today's highly mediated world, the phenomenon of 'double violation,' whereby the shame of the first violation is deepened by the mediation of it, is particularly relevant. In life-writing contexts, the violation can be repeated or rejected, and the public orientation of the ghost-written autobiography is an especially interesting example of how individual contributions are made to debates on sexual violence. However, a perceived crisis in feminist thinking on the question of sexual violence hinges on the problem of sympathy with the perpetrator, particularly in cases of acquaintance rape, as illustrated by the Assange case in particular, but also by the Polanski case.

This article has focused on the way 'scripts' of sexual violence are reiterated or rejected in ghost-written autobiographical accounts of two famous rape cases, drawing on theoretical work by Marcus and Alcoff among others. Ghost-written accounts differ from traditional biographies or autobiographies in numerous ways, but predominantly because their authorship is known to be plural. In any discussion of this topic a certain amount of slippage between media discourses and life-narratives in book form is inevitable, as the mediation of fame is inextricable from media commentary, and this has also been the case here.

In Julian Assange: The Unauthorised Biography, a text which has been disowned to varying degrees by both its named author and its (unnamed) ghost-writer O'Hagan, the women who accused Assange are openly criticized. Reference is made to Assange's ultimately good, while also flawed personality, implying that he is not the kind of person who commits rape. The supposed victims are barely described, except to refer to their weakness of character. While too much information would clearly not have been desirable, the text also does not clarify the details of the alleged incident, but makes a protestation of innocence nonetheless. What could be deemed a 'malestream' discourse is enlisted, invoking notions of 'carceral feminism,' to link the accusations against Assange to an international neoconservative plot against his organization Wikileaks. This includes describing feminism in Sweden as 'hardcore,' thus aiding a metaleptic reversal that posits the alleged perpetrator as the victim, and the alleged victims as perpetrators.

In The Girl: A Life in the Shadow of Roman Polanski by Samantha Geimer, a text which uses a first-person narrator, but which has two named co-authors, both Roman Polanski and the media industry are criticized. Geimer talks about the difficulty of calling acquaintance rape what it is, particularly as she did not feel herself to be in danger during the nonconsensual incident between the adult Polanski and her underage self. 
She describes at length the strategies by which she has tried to avoid media exposure and the ways in which her privacy as a victim was ignored. Geimer wishes that the case against Polanski simply be closed, but also seeks to correct flaws in Polanski's own published account of the events and to describe how the story has impacted upon her life. She argues against scripts of rape denial that use cultural difference as an excuse, the notion that women deserve or invite rape (particularly when underage), and is damning of the frequent tendency to blame the victim, noting insults directed at herself and her mother.

It has not been the role of this article to offer any adjudication on the two cases discussed, but it has addressed discursive elements of ghost-written autobiographical accounts of those cases. In discussing the 'scriptedness' of the representation of sexual violence, it has not been the goal here to determine whether the named authors are telling the truth or lying, were that even possible when dealing with ghost-written texts, but rather to reveal rhetorical strategies relating to sexuality and femininity. Scripts of sexual violence are ideologically contained to the degree that they engage with ingrained power relations, revealing features of discourses that might not otherwise be questioned. The use of scripts inevitably reduces the reader's empathy for an auto/biographical subject on a narrative level, and has a knock-on effect on the reception of the subject's work. While Julian Assange's account of the allegations made against him does not support the classic rape script that 'women deserve rape,' it comes close to the kind of 'script of denial' that attempts to blur the issue of consent. There are potentially genuine concerns about who is telling the truth in the Assange case, but the attack on feminism in the Unauthorised Autobiography undermines rather than supports the idea that his accusers are lying, because it is enlisted to construct a notion of Assange as a victim of his fame. By contrast, Samantha Geimer's support for the idea that Polanski has also been victimized, again due to his celebrity, goes hand in hand with an articulation of her side of the story and a two-way criticism of both Polanski and the media. The even-handedness and discursive awareness of Geimer's account lends it plausibility and, when read against the Assange text, helps demonstrate how rape scripts are perpetuated, in life-writing as elsewhere, while also showing ways such scripts can be resisted.

\section{WORKS CITED}

Alcalde, M. Cristina. "Ripped from the Headlines: Newspaper Depictions of Battered Women in Peru." Eds. Lisa M. Cuklanz and Sujata Moorti. Local Violence, Global Media: Feminist Analyses of Gendered Representations. New York, Washington DC: Peter Lang, 2009. 46-64. 
Alcoff, Linda Martín. "Then and Now." The Journal of Speculative Philosophy 26.2 (2012): 26878.

Alcoff, Linda Martín. "Discourses of Sexual Violence in a Global Context." Ed. Alison M. Jaggar. Gender and Global Justice. Cambridge and Malden: Polity Press, 2014. 119-46.

Alcoff, Linda Martín and Laura Gray-Rosendale. "Survivor Discourse: Transgression or Recuperation?" Eds. Sidonie Smith and Julia Watson. Getting a Life: Everyday Uses of Autobiography. Minneapolis and London: University of Minnesota Press, 1996.

Assange, Julian. The Unauthorised Autobiography. Edinburgh: Canongate, 2011.

Axelsson, Katrin. "Dominique Strauss-Kahn: Prejudice and Politics Shape A Rape Case Again.” The Guardian 3 Jul. 2011, http://www.theguardian.com/commentisfree/2011/ jul/03/dominique-strauss-kahn-prejudice-politics. Web. 31 Mar. 2014.

Axelsson, Katrin and Lisa Longstaff. "We are Women Against Rape but we do not want Julian Assange extradited.” The Guardian 23 Aug. 2012, http://www.theguardian.com/commentisfree/2012/aug/23/women-against-rape-julian-assange. Web. 31 Mar. 2014.

Bourke, Joanna. Rape: A History from 1860 to the Present Day. London: Virago, 2007.

Boyle, Catherine. "DSK 'Seducer' Not Rapist: Biographer." CNBC 6 Jul. 2011, http://www. cnbc.com/id/43650051. Web. 31 Mar. 2014.

Butler, Judith and Joan Scott. Feminists Theorize the Political. New York: Routledge, 1992.

Cahill, Anne J. Rethinking Rape. Ithaca and London: Cornell University Press, 2001.

Cesarani, David. Arthur Koestler. The Homeless Mind. London: Heinemann, 1998.

Coetzee, John Maxwell. Diary of a Bad Year. London: Harvill \& Secker, 2007.

Cuklanz, Lisa M. and Sujata Moorti, eds. Local Violence, Global Media: Feminist Analyses of Gendered Representations. New York, Washington DC: Peter Lang, 2009.

Davis, Kathy. "'Stand by Your Man' or: How Feminism was Framed in the DSK Affair.' European Journal of Women's Studies 19.3 (2012): 3-6.

Frank, Gelya. "'Becoming the Other': Empathy and Biographical Interpretation." Biography 8.3 (1985): 189-210.

Geimer, Samantha and Lawrence Silver with Judith Newman. The Girl. A Life in the Shadow of Roman Polanski. London: Simon \& Schuster, 2013.

Gilmore, Leigh. The Limits of Autobiography: Trauma and Testimony. Ithaca and London: Cornell University Press, 2001.

Gunne, Sorcha and Zoë Brigley Thompson, eds. Feminism, Literature and Rape Narratives: Violence and Violation. New York and London: Routledge, 2010.

Higgins, Lynn A. and Brenda R. Silver, eds. Rape and Representation. New York: Columbia University Press, 1991a.

Higgins, Lynn A. and Brenda R. Silver. "Introduction: Rereading Rape." Eds. Higgins and Silver. Rape and Representation. New York: Columbia University Press, 1991b.

Horeck, Tanya. Public Rape: Representing Violation in Fiction and Film. London and New York: Routledge, 2004.

Jaggar, Alison M. ed. Gender and Global Justice. Cambridge and Malden: Polity Press, 2014.

Judt, Tony. Reappraisals. Reflections on the Forgotten Twentieth Century. London: Vintage, 2009.

Kabir, Ananya Jahanara. "Double Violation? (Not) Talking about Sexual Violence in Contemporary South Asia." Eds. Sorcha Gunne and Zoë Brigley Thompson. Feminism, Literature and Rape Narratives: Violence and Violation. New York and London: Routledge, 2010. 146-63.

Marcus, Sharon. "Fighting Bodies, Fighting Words: A Theory and Politics of Rape Prevention." Eds. Judith Butler and Joan Scott. Feminists Theorize the Political. New York: Routledge, 1992. 385-404.

Mardorossian, Carine M. "Toward a New Feminist Theory of Rape." Signs 27.3 (2002): 74375 .

O’Hagan, Andrew. "Ghosting." London Review of Books 36.5 (2014): 5-26. 
O'Toole, Laura, Jessica R. Schiffman, and Margie L. Kiter Edward, eds. Gender Violence. Interdisciplinary Perspectives. 2nd ed. New York and London: New York University Press, 2007.

Polanski, Roman. Roman. London: Pan, 1985 [1984].

Rollyson, Carl. To Be a Woman: The Life of Jill Craigie. London: Aurum, 2005.

Rollyson, Carl. Biography: A User's Guide. Chicago: Ivan R. Dee, 2008.

Rouyer, Muriel. "The Strauss-Kahn Affair and the Culture of Privacy: Mistreating and Misrepresenting Women in the French Public Sphere." Women's Studies International Forum 41 (2013): 187-96.

Price, Matthew. "Who Owns Arthur Koestler? A Biographers' Row.” Lingua Franca Sep. 1999. $63-7$.

Sasse, Sabine."Die Justiz und die Medien. Die Berichterstattung im Prozess gegen den TVModerator Andreas Türck." Eds. Christian Schertz and Thomas Schuler. Rufmord und Medienopfer. Die Verletzung der persönlichen Ehre. Berlin: Ch. Links Verlag, 2007. 69-80.

Scammell, Michael. Koestler. The Literary and Political Odyssey of a Twentieth-Century Skeptic. New York: Random House, 2009.

Scully, Diana and Joseph Marolla. "Convicted Rapists' Vocabulary of Motive: Excuses and Justifications.” Ed. Henry N. Pontell. Social Deviance: Readings in Theory and Research. Englewood Cliffs: Prentice Hall, 1993. 252-67.

Smith, Valerie. Not Just Race, Not Just Gender. Black Feminist Readings. New York and London: Routledge, 1998.

Smith, Sidonie and Julia Watson, eds. Getting a Life: Everyday Uses of Autobiography. Minneapolis and London: University of Minnesota Press, 1996.

Spade, Dean and Craig Willse. "Sex, Gender, and War in an Age of Multicultural Imperialism." QED. A Journal in GLBTQ Worldmaking 1.1 (2014): 5-29.

Stillinger, Jack. Multiple Authorship and the Myth of Solitary Genius. Oxford: Oxford University Press, 1991.

UN Women. "Facts and Figures: Ending Violence against Women." http://www.unwomen. org/en/what-we-do/ending-violence-against-women/facts-and-figures. Web. 5 Nov. 2014.

Volkening, Heide. Am Rand der Autobiographie: Ghostwriting - Signatur - Geschlecht. Bielefeld: Transcript, 2006.

White Stewart, Mary. "Real Victims, Reasonableness, and Rape.” Eds. Laura O’Toole, Jessica R. Schiffman, and Margie L. Kiter Edwards. Gender Violence. Interdisciplinary Perspectives. 2nd ed. New York and London: New York University Press, 2007. 205-13.

\section{ABOUT THE AUTHOR}

Edward Saunders is a researcher at the Ludwig Boltzmann Institute for the History and Theory of Biography in Vienna, Austria. He holds a PhD in German Studies from the University of Cambridge (2013) and is interested in life-writing, literature and visual culture. He has published in German Life E Letters and has forthcoming articles in Biography and Oxford German Studies.

\section{NOTES}

1 Rollyson, Carl. To Be a Woman. The Life of Jill Craigie. London: Aurum, 2005 (p. 337).

2 The case is discussed in the following books: Cesarani, David. Arthur Koestler. The Homeless Mind. London: Heinemann, 1998 (pp. 399-401); Rollyson, Carl. To Be a Woman. The Life of 
Jill Craigie. London: Aurum, 2005 (pp. 134-7; 337-43); Judt, Tony, Reappraisals. Reflections on the Forgotten Twentieth Century. London: Vintage, 2009 (pp. 32-3); Scammell, Michael. Koestler. The Literary and Political Odyssey of a Twentieth-Century Skeptic. New York: Random House, 2009 (pp. 406-8).

3 Price, Matthew, 'Who Owns Arthur Koestler? A Biographers' Row.' Lingua Franca, September 1999 (63-7 (64)).

4 There have been extensive discussions on definitions of rape, sexual violence and sexual assault. A useful overview of feminist discussions, including a critique of the influential work of Susan Brownmiller and Catharine MacKinnon, can be found in Anne J. Cahill: Rethinking Rape. Ithaca and London: Cornell University Press, 2001 (pp. 15-49).

5 Coetzee, John Maxwell, Diary of a Bad Year. London: Harvill \& Secker, 2007 (pp. 100-101).

6 On ghost-writing and autobiography see e.g. Jack Stillinger, Multiple Authorship and the Myth of Solitary Genius. Oxford: Oxford University Press, 1991 (pp. 50-3); Heide Volkening, Am Rand der Autobiographie: Ghostwriting - Signatur - Geschlecht. Bielefeld: Transcript, 2006.

7 M. Cristina Alcalde, 'Ripped from the Headlines: Newspaper Depictions of Battered Women in Peru.' In: Lisa M. Cuklanz and Sujata Moorti (eds.), Local Violence, Global Media: Feminist Analyses of Gendered Representations. New York, Washington DC: Peter Lang, 2009 (pp. 46-64 (p. 61)).

8 Horeck, Tanya, Public Rape: Representing Violation in Fiction and Film. London and New York: Routledge, 2004 (p. 154).

9 Horeck 2004 (p. 155).

10 Alcoff, Linda Martín, 'Then and Now.' The Journal of Speculative Philosophy 26:2, 2012 (268-78 (273)).

11 Alcoff 2012, 'Then and Now' (274).

12 Alcoff 2012, 'Then and Now' (274-5).

13 Marcus, Sharon, 'Fighting Bodies, Fighting Words: A Theory and Politics of Rape Prevention.' In: Judith Butler and Joan Scott (eds.), Feminists Theorize the Political. New York: Routledge, 1992 (pp. 385-404 (p. 389)).

14 Scully, Diana and Joseph Marolla, 'Convicted Rapists' Vocabulary of Motive: Excuses and Justifications.' In: Henry N. Pontell (ed.), Social Deviance: Readings in Theory and Research. Englewood Cliffs: Prentice Hall, 1993 (pp. 252-67 (p. 264)).

15 Idem.

16 Idem.

17 Idem.

18 Bourke, Joanna, Rape: A History from 1860 to the Present Day. London: Virago, 2007 (pp. 25, 28, 42, 49).

19 Rollyson, Carl. Biography. A User's Guide. Chicago: Ivan R. Dee, 2008 (p. 12).

20 Rollyson 2008 (p. 288).

21 O'Hagan, Andrew, 'Ghosting.' London Review of Books 36:5, 2014 (5-26 (5; 20-4)).

22 O’Hagan, 'Ghosting' (18-20).

23 O’Hagan, 'Ghosting' (12).

24 Assange, Julian, The Unauthorised Autobiography. Edinburgh: Canongate, 2011 (p. 236).

25 Boyle, Catherine, 'DSK “Seducer" Not Rapist: Biographer.' CNBC, 6 July 2011, http:// www.cnbc.com/id/43650051. Web. 31 March 2014.

26 UN Women, 'Facts and Figures: Ending Violence against Women', http://www.unwomen.org/en/what-we-do/ending-violence-against-women/facts-and-figures. Web. 5 November 2014.

27 Assange 2011 (p. 237).

28 Spade, Dean and Craig Willse, 'Sex, Gender, and War in an Age of Multicultural Imperialism'. QED: A Journal in LGBTQ Worldmaking 1:1, 2014 (5-29 (15)). 
29 Axelsson, Katrin and Lisa Longstaff, 'We are Women Against Rape but we do not want Julian Assange extradited.' The Guardian, Thursday 23 August 2012, http://www.theguardian.com/commentisfree/2012/aug/23/women-against-rape-julian-assange. Web. 31 March 2014.

30 Axelsson, Katrin, 'Dominique Strauss-Kahn: prejudice and politics shape a rape case again.' The Guardian, 3 July 2011, http://www.theguardian.com/commentisfree/2011/ jul/03/dominique-strauss-kahn-prejudice-politics. Web. 31 March 2014.

31 Davis, Kathy, "Stand by your man" or: How feminism was framed in the DSK affair', European Journal of Women's Studies 19:3, 2012 (3-6 (5)).

32 Rouyer, Muriel, 'The Strauss-Kahn affair and the culture of privacy: mistreating and misrepresenting women in the French public sphere', Women's Studies International Forum 41, 2013 (187-96 (188)).

33 Rouyer 2013 (p. 189).

34 Assange 2011 (p. 231).

35 Assange 2011 (p. 232).

36 Assange 2011 (p. 233).

37 Assange 2011 (pp. 234-5).

38 Assange 2011 (p. 236).

39 Assange 2011 (p. 240).

40 O'Hagan, 'Ghosting' (18).

41 O'Hagan, 'Ghosting' (25).

42 O'Hagan, 'Ghosting' (21).

43 Mardorossian, Carine M., 'Toward a New Feminist Theory of Rape.' Signs 27:3, 2002 (743-75 (756)).

44 Mardorossian 2002 (767).

45 Higgins, Lynn A. and Brenda R. Silver, 'Introduction: Rereading Rape.' In: Higgins and Silver (eds.), Rape and Representation, New York: Columbia University Press, 1991 (pp. 1-11 (p. 4)).

46 Geimer, Samantha and Lawrence Silver with Judith Newman, The Girl. A Life in the Shadow of Roman Polanski. London: Simon \& Schuster, 2013. (p. 196).

47 Geimer et al 2013 (p. 8).

48 Polanski, Roman, Roman, London: Pan, 1985 [1984]. (p. 403).

49 Geimer et al 2013 (p. 83).

50 Geimer et al 2013 (p. 84).

51 Idem.

52 White Stewart, Mary. "Real Victims, Reasonableness, and Rape.” Eds. Laura O’Toole, Jessica R. Schiffmann, and Margie L. Kiter Edwards. Gender Violence. Interdisciplinary Perspectives. 2nd ed. New York and London: New York University Press, 2007 (205-13 (207)).

53 White Stewart 2007 (p. 212).

54 Alcoff, Linda Martín, 'Discourses of Sexual Violence in a Global Context.' In: Alison M. Jaggar (ed.), Gender and Global Justice. Cambridge and Malden: Polity Press, 2014 (pp. 119-46 (p. 129)).

55 Cesarani 1998 (p. 562).

56 Geimer et al 2013 (p. 52).

57 Geimer et al 2013 (p. 157).

58 Alcoff 2014, 'Discourses of Sexual Violence' (p. 123).

59 Alcoff 2014, 'Discourses of Sexual Violence' (p. 145).

60 Polanski 1985 (p. 393).

61 Geimer 2013 (pp. 39-40; p. 105). Cf: Bourke 2007 (pp. 403-4).

62 Geimer 2013 (p. 120). 
63 Geimer 2013 (p. 233).

64 Geimer 2013 (pp. 212-3).

65 Kabir, Ananya Jahanara, 'Double Violation? (Not) Talking about Sexual Violence in Contemporary South Asia', in Sorcha Gunne and Zoë Brigley Thompson (eds.), Feminism, Literature and Rape Narratives: Violence and Violation. New York and London: Routledge, 2010 (pp. 146-63 (p. 150)).

66 Geimer 2013 (p. 64).

67 Geimer 2013 (p. 236).

68 Geimer 2013 (p. 239).

69 Kabir, Ananya Jahanara 2010 (p. 154).

70 Geimer 2013 (pp. 221-2). 